ry, and fills a sizeable gap in the literature. Little work on Great War COs has been done in comparison with Second World War objectors, while works on reactions from labour groups or religious orders only mentions objectors in passing. In addition, these works do not attempt to view the objector's own views comparatively or draw wider observations of the issue. Though important works on Canadian pacifism such as Thomas Socknat's Witness Against War: Pacifism in Canada, 1900-1945 (1987) provide a useful overview there is much ground left to cover. Additionally, while many theoretical or sociological works on pacifism shed light on the issue, they lack a historical view to "place their objection in its appropriate context" as "it is important to examine what elements ion Canadian society affected the decision to object, the experience of objection and how mainstream society viewed the COs." (6)

While the lack of a thorough use of documentary sources is often crippling to a work, Shaw points out that the majority of the COs records were destroyed by Chief Justice Lyman P. Duff shortly after the war. This forced the author to rely on newspaper accounts which were often sensationalistic or provided only rudimentary information. These setbacks notwithstanding, Shaw has painstakingly attempted to reconstruct as complete a list as possible based on sources ranging from newspapers accounts to military attestation papers and leaves the reader with a sound analysis.

Shaw's Crisis of Confidence in an interesting and valuable first look at a hitherto neglected component of the Canadian Great War experience and will prove useful to both general readers and specialists seeking new examinations and approaches for many issues pertaining to the first two decades of the twentieth century.

Tavis Harris

Wilfred Laurier University

\title{
Bruce Baum and Duchess Harris, eds. Racially Writing the Republic: Racists, Race Rebels, and Transformations of American Identity (Durham: Duke University Press, 2009).
}

This fine collection of essays seeks to write race back into our historical and political narratives of the United States. By collecting a variety of essays from multiple disciplines, the editors revisit the role of race and racism in the development of American political thought and national identity. Essays on canonical American thinkers and political actors such as Thomas Jefferson, George Washington, and Abraham Lincoln make clear the ways in which America's founding ideals of liberty and democracy were informed by a racially defined vision. The book, therefore, commits itself to "exposing the false neutrality of a racially white America that their [the canonical thinkers'] theories presume and to 
making visible the various ways in which exclusionary racialized power has been deployed in the construction of American identity, freedom, and citizenship" (5).

Not content to simply write race back into America political thought, the editors have also collected essays on a number of "race rebels" whose writings and actions challenged the racial status quo. These race rebels range from the well-known - W.E.B. Du Bois, Ida B. Wells-Barnett, and James Baldwin - to the lesser known - Mexican Texan rebel Juan Nepomuceno Cortina; memoirist and daughter of Chief Winnemucca of the Northern Paiutes, Sarah Winnemucca; Filipino American poet and migrant worker, Carlos Bulosan; and playwright Lorraine Hansberry. Each of these race rebels strove for a social justice informed by their own racialized identity, while maintaining a belief in the American ideals characterized by the canonical writers and thinkers. Ultimately, the editors view the book as part of a larger political project that intends to make clear the current racial challenges faced by Americans and give hope to those who continue to strive for an antiracist American republic.

Like all collections of essays some of the material in Racially Writing the Republic does not meet the editors' intended goals. Unfortunately, this occurs most often with essays that seek to break free from the black/white paradigm that has - for good reason - so often dominated writing on race in America. One example is Jerry Thompson's “'The Sacred Right of Self-Preservation': Juan Nepomuceno Cortina and the Struggle for Justice in Texas." Thompson's essay does an excellent job of communicating the reasons for and the events surrounding Cortina's rebellion against Anglo Americans in Texas, but leaves the reader unsure of the role race played in Cortina's War. Was Cortina's motivation for violent guerrilla warfare based on establishing "racial equality in Texas" or was his motivation stemming from his class and nationalist interests as a "Mexican Texan" or "Tejano" (81)? Perhaps the reason why some of the material does not quite succeed is that it is making up for lost ground. Scholarship seeking to break free from the black/white paradigm must first bear witness to the existence of alternative race relations and identities that have long been hidden or wilfully neglected before delving deeper into how they have contributed to such broad categories as American political thought and identity.

Nevertheless, Racially Writing the Republic opens doors to explore race in the United States outside of the black/white binary and indicates the ways in which power in America is intertwined in a complex matrix of racial, gender, class, national, and sexual identities.

The majority of essays, however, do succeed in writing race back into American political thought. Notable highlights include Catherine A. Holland's "Shoot Mr. Lincoln", which suggests that Lincoln was not torn between idealist and racist selves but was the embodiment of the American liberal tradition. Holland also asks us to perform a provocative thought-experiment and ask what if Lincoln was black? Joel Olson presents a nuanced reading of the transforma- 
tion of race in the work of W.E.B. Du Bois, moving from a biological essentialism to cultural and geographical environmentalism to social construction. Lastly, Dorothy Roberts' essay on Margaret Sanger and the role racism and eugenics played in propelling forward the birth control movement gives one pause to the pervasive role race has played in everyday American life.

In many ways this collection of essays crosses familiar ground, historians of American political thought have long connected racial and gender exclusion to the nation's ideals of liberty and democracy. Moreover, two essays Gwendolyn Mink's and Gary Gerstle's - date from 1986 and 1999 and one wonders if the editors could have drawn from more recent scholarship. What Racially Writing the Republic does add to our understanding of the American political legacy is the way in which multiple identities outside of the white/black paradigm have had a lasting effect on the nation. By "re-writing" race into the United States' historical and political narratives, Baum and Harris have given us the tools to examine the ways in which race and racism continue to define the core beliefs of American identity and society. As George Lipsitz's excellent afterword on the troubling legacy of school segregation makes clear, racism continues to dog everyday life for all Americans. In the end, Baum and Harris' collection of essays makes us wonder who are the race rebels of today and why are there not more of them?

\author{
Nathan C.A. Cardon
} University of Toronto

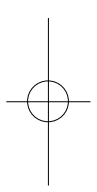

\title{
Brian McGinty, Jobn Brown's Trial (Cambridge, Mass.: Harvard University Press, 2009).
}

It may be typical to laud a praiseworthy biography as "the standard for judging the literature," but in the estimation of this biographer there is little exaggeration in saying that John Brown's Trial by Brian McGinty is a singular and unparalleled standard for the study of the most important chapter in the life of the abolitionist. McGinty, an attorney and a seasoned historian, has provided the first fully developed study of the trial of Brown in Jefferson County, Virginia. Brown has been widely misrepresented and frequently misunderstood by historians, but he is popularly remembered for his failed effort to initiate a slave liberation movement by seizing a federal armoury in the town of Harper's Ferry, Virginia, on October 16, 1859. Brown scholars have usually sampled aspects of his trial, but no writer has provided a full examination of the legal character of the story. Yet McGinty does so in a manner readable and at times quite enthralling. The reader may sense some admiration for Brown too, but the author holds both him and his Virginia prosecutors up to the light of a cool, balanced, and reasoned analysis. 